\title{
PENINGKATAN KEMAMPUAN BERKOMUNIKASI DENGAN PESERTA DIDIK MELALUI SUPERVISI KLINIS BAGI GURU SD NEGERI 5 SURABAYA PADA SEMESTER I TAHUN AJARAN 2016/2017
}

\author{
Vera Vonette ${ }^{1)}$, Ian Indrata ${ }^{2)}$, Hasondrorogo Daya ${ }^{3)}$, Elisabet Kristanti ${ }^{4)}$, Arlawati Ginting ${ }^{5)}$ \\ 1) Sekolah Tinggi Teologia Abdi Gusti, Nganjuk, Indonesia \\ E-mail:vera@sttabdigusti.ac.id \\ 2) Sekolah Tinggi Teologia Abdi Gusti, Nganjuk, Indonesia \\ E-mail:ian@sttabdigusti.ac.id \\ 3) Sekolah Tinggi Teologia Abdi Gusti, Nganjuk, Indonesia \\ E-mail: hason@sttabdigusti.ac.id \\ 4) Sekolah Tinggi Teologia Abdi Gusti, Nganjuk, Indonesia \\ E-mail: elisabet@sttabdigusti.ac.id \\ 5) Sekolah Tinggi Teologia Abdi Gusti, Nganjuk, Indonesia \\ E-mail: arlawati@sttabdigusti.ac.id
}

\begin{abstract}
Abstrak. The ability of teachers to manage student interactions in learning activities relates to communication between students and other students, students with teachers and vice versa. The purpose of this study was to measure the improvement in the ability of Surabaya Elementary School 5 teachers to communicate with students after clinical supervision. This classroom action research was carried out by taking place at SD Negeri 5 Surabaya. The school's action research was conducted in the first semester of the 2016/2017 school year. The subject of this study was the teacher of SD Negeri 5 Surabaya, amounting to six teachers. The results of this study are the teacher's ability to communicate with students from cycle to cycle has increased, namely from prasiklus $33.86 \%$, the first cycle of $66.08 \%$, and the second cycle of $88.30 \%$, so that the increase during the action is 54, 44\%. Increases occur in all aspects. The increase in teachers' abilities was due to clinical supervision activities based on objective assessments that were delivered transparently to teachers, besides the implementation of supervision with a small number of teachers tended to facilitate communication between researchers, principals and teachers. The existence of such supervision increases the teacher's awareness of the importance of the ability to communicate with students, and raises the awareness of teachers that this ability is one aspect of teacher performance assessment.
\end{abstract}

Keywords: ability, communication, clinical supervision.

\section{PENDAHULUAN}

Guru merupakan orang yang melaksanakan pendidikan di tempat-tempat tertentu dan memberikan ilmu pengetahuan, tidak mesti di lembaga pendidikan formal, tetapi bisa di mana saja. Jadi, kompetensi guru adalah seperangkat pengetahuan, keterampilan, dan perilaku yang harus dimiliki, dihayati, dikuasai, dan diwujudkan oleh guru dalam melaksanakan tugas keprofesionalnya. Kompetensi guru dapat dimaknai sebagai kebulatan pengetahuan, keterampilan dan sikap yang berwujud tindakan cerdas dan penuh tanggung jawab dalam melaksanakan tugas sebagai agen pembelajaran. Untuk dapat melaksanakan tugas tersebut dengan baik, selain harus memenuhi syarat-syarat kedewasaan, sehat jasmani dan rohani, guru juga harus memiliki ilmu dan kecakapan keterampilan keguruan. Ilmu dan kecakapan keterampilan tersebut diperoleh selama menempuh pelajaran di lembaga pendidikan guru. Ada beberapa sifat dan sikap yang harus dimiliki oleh guru profesional, 
yaitu: Fleksibel, Bersikap terbuka, Berdiri sendiri, Peka, Tekun, Realistik, Melihat ke depan, Rasa ingin tahu. Ekspresif, Menerima diri. Maka, guru dituntut harus kreatif, profesional, dan menyenangkan, dengan memposisikan diri sebagai : (a) orang tua yang penuh kasih sayang pada peserta didiknya, (b) teman, tempat mengadu, dan mengutarakan perasaan bagi para peserta didik, (c) fasilitator yang selalu siap memberikan kemudahan, dan melayani peserta didik sesuai minat, Keterampilan, dan bakatnya (d) memberikan sumbangan pemikiran kepada orang tua untuk dapat mengetahui permasalahan yang dihadapi anak dan memberikan saran pemecahannya, (e) memupuk rasa percaya diri, berani dan bertanggung jawab, (f) membiasakan peserta didik untuk saling berhubungan (bersilaturahmi) dengan orang lain secara wajar, (g) mengembangkan proses sosialisasi yang wajar antar peserta didik, orang lain, dan lingkungannya, (h) mengembangkan kreativitas, dan (i) menjadi pembantu ketika diperlukan.

Pembelajaran merupakan suatu proses komunikasi. Komunikasi adalah proses pengiriman informasi dari guru kepada siswa untuk tujuan tertentu. Komunikasi dikatakan efektif apabila komunikasi yang terjadi menimbulkan arus informasi dua arah, yaitu dengan munculnya feedback dari pihak penerima pesan. Kualitas pembelajaran dipengaruhi oleh efektif tidaknya komunikasi yang terjadi di dalamnya. Tujuan pendidikan akan tercapai jika prosesnya komunikatif. Keberhasilan pembelajaran harus didukung oleh komponenkomponen instruksional yang terdiri dari pesan berupa materi belajar, penyampai pesan yaitu guru, bahan untuk menuangkan pesan, peralatan yang mendukung kegiatan belajar, teknik atau metode yang sesuai, serta latar atau situasi yang kondusif bagi proses pembelajaran.

Maka, seorang guru harus komunikatif berkomunikasi dengan peserta didik karena pekerjaan rutin bagi guru. Baik dalam rangka pemyampaikan materi pelajaran, memberikan nasehat, saran, maupun pendapat. Sebagai pengajar dan pendidik tentunya komunikasi dengan peserta didik tidak terbatas pada bagaimana peserta didik dapat memahami apa yang diajarkan, tetapi juga harus memikirkan bagaimana cara mementuk perilaku dan budi pekerti peserta didik menjadi lebih baik.

Sesuai dengan pedoman penilaian kinerja guru, khususnya kemampuan guru dalam berkomunikasi dengan peserta didik telah ditetapkan beberapa indikator yaitu: (1) Cara Guru menggunakan pertanyaan untuk mengetahui pemahaman dan menjaga partisipasi peserta didik, termasuk memberikan pertanyaan terbuka yang menuntut peserta didik untuk menjawab dengan ide dan pengetahuan mereka, (2) Cara guru memberikan perhatian dan mendengarkan semua pertanyaan dan tanggapan peserta didik, tanpa menginterupsi, kecuali jika diperlukan untuk membantu atau mengklarifikasi pertanyaan/tanggapan tersebut, (3) Cara Guru menanggapi pertanyaan peserta didik secara tepat, benar, dan mutakhir, sesuai tujuan pembelajaran dan isi kurikulum, tanpa mempermalukannya, (4) Cara Guru menyajikan kegiatan pembelajaran yang dapat menumbuhkan kerja sama yang baik antar pserta didik, (5) Cara Guru mendengarkan dan memberikan perhatian terhadap semua jawaban peserta didik baik yang benar maupun yang dianggap salah untuk mengukur tingkat pemahaman peserta didik, dan (6) Cara Guru memberikan perhatian terhadap pertanyaan peserta didik dan meresponnya secara lengkap dan relevan untuk menghilangkan kebingungan pada peserta didik.

Kemampuan guru untuk mengelola interaksi peserta didik dalam kegiatan pembelajaran berhubungan dengan komunikasi antara peserta didik dengan peserta didik lain, peserta didik dengan guru dan sebaliknya. Agar semua siswa dapat berpartisipasi dan berinteraksi secara optimal, guru mengelola interaksi tidak hanya searah saja yaitu dari guru ke siswa atau dua arah dari guru ke siswa dan sebaliknya, melainkan diupayakan adanya interaksi multi arah yaitu dari guru ke siswa, dari siswa ke guru dan dari siswa ke siswa.

Dalam proses pembelajaran komunikasi dilakukan oleh guru dapat dilihat dari aspek bagaimana guru menggunakan pertanyaan untuk mengetahui pemahaman dan menjaga partisipasi peserta didik, bagaimana guru memberikan perhatian dan mendengarkan semua pertanyaan dan tanggapan peserta didik, tanpa menginterupsi, bagaimana cara Guru menanggapi pertanyaan peserta didik secara tepat, benar, dan 
mutakhir, sesuai tujuan pembelajaran dan isi kurikulum, tanpa mempermalukannya, bagaimana cara Guru menyajikan kegiatan pembelajaran yang dapat menumbuhkan kerja sama yang baik antar pserta, bagaimana cara Guru mendengarkan dan memberikan perhatian terhadap semua jawaban peserta didik baik yang benar maupun yang dianggap salah untuk mengukur tingkat pemahaman peserta didik, dan bagaimana cara Guru memberikan perhatian terhadap pertanyaan peserta didik dan meresponnya secara lengkap dan relevan untuk menghilangkan kebingungan pada peserta didik.

Kenyataan di SD Negeri 5 Surabaya indikator tersebut sering terabaikan, seperti guru terkadang memotong pertanyaan siswa sebelum siswa selesai mengutarakan apa yang ditanyakan, terkadang guru lupa memberikan pertanyaan untuk mengetahui tingkat pemahaman siswa, guru tersenyum pada saat siswa bertanya dan hal itu dianggap oleh siswa sebagai sikap yang seakan-akan mencemooh, guru tidak memberikan kesempatan kepada siswa untuk memecahkan persoalan bersama sehingga guru kurang dapat menciptakan kerjasama yang baik.

Sewajarnya guru adalah sebagai contoh melalui pembinaan dan penilaian yang obyektif, hasilnya dapat digunakan sebagai evaluasi kemampuan guru dan sebagai bahan masukan untuk meningkatkan kemampuan guru. Melalui pembinaan yang berdasarkan kekurangan guru, arah pembinaan lebih tepat dan terarah, sehingga dapat meningkatkan kemampuan guru.

Sehubungan dengan masalah tersebut, dapat dirumuskan masalah, yaitu:

1. Apakah melalui supervisi klinis kemampuan berkomunikasi dengan peserta didik bagi guru SD Negeri 5 Surabaya pada semester I tahun ajaran 2016/2017 meningkat?

2. Apakah melalui supervisi klinis kemampuan berkomunikasi dengan peserta didik bagi guru SD Negeri 5 Surabaya pada semester I tahun ajaran 2016/2017 meningkat?

\section{Landasan Teori}

Menurut Djamarah (2005 : 31) guru adalah orang yang memberikan ilmu pengetahuan kepada anak didik. Guru dalam pandangan masyarakat adalah orang yang melaksanakan pendidikan di tempat-tempat tertentu, tidak mesti di lembaga pendidikan formal, tetapi bisa di mana saja. Sarimaya (2008 : 17) mengemukakan kompetensi guru merupakan seperangkat pengetahuan, keterampilan, dan perilaku yang harus dimiliki, dihayati, dikuasai, dan diwujudkan oleh guru dalam melaksanakan tugas keprofesionalnya. Ditampilkan melalui unjuk kerja. Kompetensi guru dapat dimaknai sebagai kebulatan pengetahuan, keterampilan dan sikap yang berwujud tindakan cerdas dan penuh tanggung jawab dalam melaksanakan tugas sebagai agen pembelajaran.

Guru merupakan suatu pekerjaan profesional. Untuk dapat melaksanakan tugas tersebut dengan baik, selain harus memenuhi syarat-syarat kedewasaan, sehat jasmani dan rohani, guru juga harus memiliki ilmu dan kecakapan keterampilan keguruan. Ilmu dan kecakapan keterampilan tersebut diperoleh selama menempuh pelajaran di lembaga pendidikan guru (Sukmadinata, 2007 : 255). Ada beberapa sifat dan sikap yang harus dimiliki oleh guru profesional, yaitu: Fleksibel, Bersikap terbuka, Berdiri sendiri, Peka, Tekun, Realistik, Melihat ke depan, Rasa ingin tahu, Ekspresif, Menerima diri.

Dalam hal ini, guru harus kreatif, profesional, dan menyenangkan, dengan memposisikan diri (Mulyasa, 2006 : 36) sebagai berikut: (a) orang tua yang penuh kasih sayang pada peserta didiknya, (b) teman, tempat mengadu, dan mengutarakan perasaan bagi para peserta didik, (c) fasilitator yang selalu siap memberikan kemudahan, dan melayani peserta didik sesuai minat, Keterampilan, dan bakatnya (d) memberikan sumbangan pemikiran kepada orang tua untuk dapat mengetahui permasalahan yang dihadapi anak dan memberikan saran pemecahannya, (e) memupuk rasa percaya diri, berani dan bertanggung jawab, (f) membiasakan peserta didik untuk saling berhubungan (bersilaturahmi) dengan orang lain secara wajar, (g) mengembangkan proses sosialisasi yang wajar antar peserta didik, orang lain, dan lingkungannya, (h) mengembangkan kreativitas, dan (i) menjadi pembantu ketika diperlukan.

Pembelajaran merupakan suatu proses komunikasi. Komunikasi adalah proses pengiriman informasi dari guru kepada siswa untuk tujuan tertentu. Komunikasi dikatakan efektif apabila komunikasi yang terjadi 
menimbulkan arus informasi dua arah, yaitu dengan munculnya feedback dari pihak penerima pesan. Kualitas pembelajaran dipengaruhi oleh efektif tidaknya komunikasi yang terjadi di dalamnya. Tujuan pendidikan akan tercapai jika prosesnya komunikatif. Keberhasilan pembelajaran harus didukung oleh komponenkomponen instruksional yang terdiri dari pesan berupa materi belajar, penyampai pesan yaitu guru, bahan untuk menuangkan pesan, peralatan yang mendukung kegiatan belajar, teknik atau metode yang sesuai, serta latar atau situasi yang kondusif bagi proses pembelajaran (Basamala, $2012: 4)$.

Iklim komunikatif yang baik dalam hubungan interpersonal antara guru dengan guru, guru dengan siswa, dan siswa dengan siswa merupakan kondisi yang memungkinkan berlangsungnya proses belajar mengajar yang efektif, karena setiap personal diberi kesempatan untuk ikut serta dalam kegiatan di dalam kelas sesuai dengan kemampuan masing-masing. Sehingga timbul situasi sosial dan emosional yang menyenangkan pada tiap personal, baik guru maupun siswa dalam melaksanakan tugas dan tanggung jawab masing-masing (DeVito, 2007 : 74).

Dengan terjalinnya keterbukaan, masingmasing pihak merasa bebas bertindak, saling menjaga kejujuran dan saling berguna bagi pihak lain sehingga merasakan adanya wahana tempat bertemunya kebutuhan mereka untuk dipenuhi secara bersama-samam (Effendy, 2008: 64).

Menurut Sagala (2009 : 194) supervisi adalah sebagai bantuan dan bimbingan profesional bagi guru dalam melaksanakan tugas instruksional guna memperbaiki hal belajar dan mengajar dengan melakukan stimulasi, koordinasi, dan bimbingan secara kontinu untuk meningkatkan pertumbuhan jabatan guru secara individual maupun kelompok. Supervisi adalah sebagai bantuan dan bimbingan atau tuntunan kearah situasi pendidikan yang lebih instruksional sebagai bagian dari peningkatan mutu pembelajaran.

\section{Metode}

Penelitian tindakan sekolah ini dilaksanakan dengan mengambil lokasi di SD Negeri 5 Surabaya. Penelitian tindakan sekolah ini dilaksanakan pada semester I tahun ajaran 2016/2017 tepatnya pada bulan Agustus 2016 sampai dengan bulan Oktober 2016.

Subjek penelitian ini adalah guru di SD Negeri 5 Surabayayang keseluruhan berjumlah 6 Guru. Adapun objek penelitian ini adalah kemampuan guru dalam berkomunikasi dengan peserta didik. Pengumpulan data dilakukan melalui observasi yaitu data yang diperoleh dari pengamatan langsung dari peristiwa pelaksanaan pembelajaran yang dilakukan oleh Subjek penelitian. Pengamatan akan dilakukan terhadap kemampuan guru dalam berkomunikasi dengan peserta didik, dan hasilnya dinilai dalam lembar observasi yang telah disiapkan. Hasil pengamatan akan dipergunakan guna menata langkah-langkah perbaikan pada siklus berikutnya.

Data dianalisis dengan analisa deskriptif. Analisis deskriptif dilakukan untuk memberi gambaran tentang hasil yang dicapai oleh guru setelah tidakan dilaksanakan terhadap seluruh pusat perhatian dalam penelitian meliputi Iangkah-langkah kegiatan pembelajaran. Dengan menyajikan tabel hasil penilaian kemampuan guru dalam komunikasi dengan peserta didik yang dilakukan oleh peneliti.

Pengumpulan data dilakukan melalui observasi yaitu data yang diperoleh dari pengamatan langsung dari peristiwa pelaksanaan pembelajaran yang dilakukan oleh Subjek penelitian. Pengamatan akan dilakukan terhadap kemampuan guru dalam berkomunikasi dengan peserta didik, dan hasilnya dinilai dalam lembar observasi yang telah disiapkan. Hasil pengamatan akan dipergunakan guna menata langkah-langkah perbaikan pada siklus berikutnya. Penelitian Tindakan Kelas (PTK) ini dilaksanakan dengan menggunakan prosedur penelitian yang dilakukan melalui siklussiklus tindakan. Tiap-tiap siklus dilaksanakan sesuai dengan perubahan yang dicapai yang mencakup perencanaan (planning), tindakan (action), observasi (observation), dan refleksi (reflection). 
1.

Tabel 1

Penilaian Kemapuan Komunikasi Guru dengan Peserta Didik Pada Kegiatan Prasiklus

\begin{tabular}{|c|c|c|c|c|}
\hline No & Indikator & $\begin{array}{c}\text { Jumlah } \\
\text { Skor }\end{array}$ & Rata-Rata & Prosentase \\
\hline 1 & $\begin{array}{l}\text { Cara Guru menggunakan pertanyaan untuk } \\
\text { mengetahui pemahaman dan menjaga partisipasi } \\
\text { peserta didik, termasuk memberikan pertanyaan } \\
\text { terbuka yang menuntut peserta didik untuk menjawab } \\
\text { dengan ide dan pengetahuan mereka. }\end{array}$ & 9 & 1,50 & 30,00 \\
\hline 2 & $\begin{array}{l}\text { Cara guru memberikan perhatian dan mendengarkan } \\
\text { semua pertanyaan dan tanggapan peserta didik, tanpa } \\
\text { menginterupsi, kecuali jika diperlukan untuk } \\
\text { membantu atau mengklarifikasi pertanyaan/tanggapan } \\
\text { tersebut }\end{array}$ & 11 & 1,83 & 36,66 \\
\hline 3 & $\begin{array}{l}\text { Cara Guru menanggapi pertanyaan peserta didik secara } \\
\text { tepat, benar, dan mutakhir, sesuai tujuan pembelajaran } \\
\text { dan isi kurikulum, tanpa mempermalukannya }\end{array}$ & 9 & 1,50 & 30,00 \\
\hline 4 & $\begin{array}{l}\text { Cara Guru menyajikan kegiatan pembelajaran yang } \\
\text { dapat menumbuhkan kerja sama yang baik antar pserta } \\
\text { didik. }\end{array}$ & 8 & 1,33 & 26,66 \\
\hline 5 & $\begin{array}{l}\text { Cara Guru mendengarkan dan memberikan perhatian } \\
\text { terhadap semua jawaban peserta didik baik yang benar } \\
\text { maupun yang dianggap salah untuk mengukur tingkat } \\
\text { pemahaman peserta didik }\end{array}$ & 12 & 2,00 & 40,00 \\
\hline 6 & $\begin{array}{l}\text { Cara Guru memberikan perhatian terhadap pertanyaan } \\
\text { peserta didik dan meresponnya secara lengkap dan } \\
\text { relevan untuk menghilangkan kebingungan pada } \\
\text { peserta didik. }\end{array}$ & 12 & 1,69 & 33,86 \\
\hline \multicolumn{3}{|c|}{ Rata-Rata } & 1,69 & 33,86 \\
\hline
\end{tabular}

2. Siklus I

Tabel 2

Penilaian Kemampuan Komunikasi Guru dengan Peserta Didik Pada Kegiatan Siklus I

\begin{tabular}{|c|c|c|c|c|}
\hline No & Indikator & $\begin{array}{c}\text { Jumlah } \\
\text { Skor }\end{array}$ & Rata-Rata & Prosentase \\
\hline 1 & $\begin{array}{l}\text { Cara Guru menggunakan pertanyaan untuk } \\
\text { mengetahui pemahaman dan menjaga partisipasi } \\
\text { peserta didik, termasuk memberikan pertanyaan } \\
\text { terbuka yang menuntut peserta didik untuk } \\
\text { menjawab dengan ide dan pengetahuan mereka. }\end{array}$ & 20 & 3,33 & 66,66 \\
\hline 2 & $\begin{array}{l}\text { Cara guru memberikan perhatian dan } \\
\text { mendengarkan semua pertanyaan dan tanggapan } \\
\text { peserta didik, tanpa menginterupsi, kecuali jika } \\
\text { diperlukan untuk membantu atau mengklarifikasi } \\
\text { pertanyaan/tanggapan tersebut }\end{array}$ & 20 & 3,33 & 66,66 \\
\hline 3 & $\begin{array}{l}\text { Cara Guru menanggapi pertanyaan peserta didik } \\
\text { secara tepat, benar, dan mutakhir, sesuai tujuan } \\
\text { pembelajaran dan isi kurikulum, tanpa }\end{array}$ & 20 & 3,33 & 66,66 \\
\hline
\end{tabular}




\begin{tabular}{|c|c|c|c|c|}
\hline & mempermalukannya & & & \\
\hline 4 & $\begin{array}{l}\text { Cara Guru menyajikan kegiatan pembelajaran } \\
\text { yang dapat menumbuhkan kerja sama yang baik } \\
\text { antar pserta didik. }\end{array}$ & 17 & 2,83 & 56,66 \\
\hline 5 & $\begin{array}{l}\text { Cara Guru mendengarkan dan memberikan } \\
\text { perhatian terhadap semua jawaban peserta didik } \\
\text { baik yang benar maupun yang dianggap salah } \\
\text { untuk mengukur tingkat pemahaman peserta didik }\end{array}$ & 20 & 3,33 & 66,66 \\
\hline 6 & $\begin{array}{l}\text { Cara Guru memberikan perhatian terhadap } \\
\text { pertanyaan peserta didik dan meresponnya secara } \\
\text { lengkap dan relevan untuk menghilangkan } \\
\text { kebingungan pada peserta didik. }\end{array}$ & 22 & 3,66 & 73,20 \\
\hline \multicolumn{3}{|c|}{ Rata-Rata } & 3,30 & 66,08 \\
\hline
\end{tabular}

3. Siklus II

Tabel 3

Penilaian Kemapuan Komunikasi Guru dengan Peserta Didik Pada Kegiatan Siklus II

\begin{tabular}{|l|l|l|l|c|}
\hline No & \multicolumn{1}{|c|}{ Indikator } & $\begin{array}{l}\text { Jumlah } \\
\text { Skor }\end{array}$ & Rata-Rata & Prosentase \\
\hline 1 & $\begin{array}{l}\text { Cara Guru menggunakan pertanyaan untuk } \\
\text { mengetahui pemahaman dan menjaga partisipasi } \\
\text { peserta didik, termasuk memberikan pertanyaan } \\
\text { terbuka yang menuntut peserta didik untuk } \\
\text { menjawab dengan ide dan pengetahuan mereka. }\end{array}$ & 26 & 4,33 & 86,60 \\
\hline 2 & $\begin{array}{l}\text { Cara guru memberikan perhatian dan } \\
\text { mendengarkan semua pertanyaan dan tanggapan } \\
\text { peserta didik, tanpa menginterupsi, kecuali jika } \\
\text { diperlukan untuk membantu atau mengklarifikasi } \\
\text { pertanyaan/tanggapan tersebut }\end{array}$ & 27 & 4,50 & 90,00 \\
\hline 3 & $\begin{array}{l}\text { Cara Guru menanggapi pertanyaan peserta didik } \\
\text { secara tepat, benar, dan mutakhir, sesuai tujuan } \\
\text { pembelajaran dan isi kurikulum, tanpa } \\
\text { mempermalukannya }\end{array}$ & 26 & 4,33 & 86,60 \\
\hline 4 & $\begin{array}{l}\text { Cara Guru menyajikan kegiatan pembelajaran } \\
\text { yang dapat menumbuhkan kerja sama yang baik } \\
\text { antar pserta didik. }\end{array}$ & 26 & 4,33 & 86,60 \\
\hline 5 & $\begin{array}{l}\text { Cara Guru mendengarkan dan memberikan } \\
\text { perhatian terhadap semua jawaban peserta didik } \\
\text { baik yang benar maupun yang dianggap salah } \\
\text { untuk mengukur tingkat pemahaman peserta didik }\end{array}$ & 27 & 4,50 & 90,00 \\
\hline 6 & $\begin{array}{l}\text { Cara Guru memberikan perhatian terhadap } \\
\text { pertanyaan peserta didik dan meresponnya secara } \\
\text { lengkap dan relevan untuk menghilangkan } \\
\text { kebingungan pada peserta didik. }\end{array}$ & 27 & 4,50 & 90,00 \\
\hline & \begin{tabular}{l} 
Rata-Rata \\
\hline
\end{tabular} & 4,41 & 8,30 \\
\hline
\end{tabular}




\section{Pembahasan}

Tabel 4.

Perbandingan Rata-Rata Skor Kemampuan Guru dalam Komunikasi dengan Peserta Didik (Prasiklus ke Siklus I dan siklus II)

\begin{tabular}{|c|c|c|c|c|}
\hline No & Indikator & Prasiklus & Siklus I & Siklus II \\
\hline 1 & $\begin{array}{l}\text { Cara Guru menggunakan pertanyaan untuk } \\
\text { mengetahui pemahaman dan menjaga partisipasi } \\
\text { peserta didik, termasuk memberikan pertanyaan } \\
\text { terbuka yang menuntut peserta didik untuk } \\
\text { menjawab dengan ide dan pengetahuan mereka. }\end{array}$ & 1,50 & 3,33 & 4,33 \\
\hline 2 & $\begin{array}{l}\text { Cara guru memberikan perhatian dan } \\
\text { mendengarkan semua pertanyaan dan tanggapan } \\
\text { peserta didik, tanpa menginterupsi, kecuali jika } \\
\text { diperlukan untuk membantu atau mengklarifikasi } \\
\text { pertanyaan/tanggapan tersebut }\end{array}$ & 1,83 & 3,33 & 4,50 \\
\hline 3 & $\begin{array}{l}\text { Cara Guru menanggapi pertanyaan peserta didik } \\
\text { secara tepat, benar, dan mutakhir, sesuai tujuan } \\
\text { pembelajaran dan isi kurikulum, tanpa } \\
\text { mempermalukannya }\end{array}$ & 1,50 & 3,33 & 4,33 \\
\hline 4 & $\begin{array}{l}\text { Cara Guru menyajikan kegiatan pembelajaran yang } \\
\text { dapat menumbuhkan kerja sama yang baik antar } \\
\text { pserta didik. }\end{array}$ & 1,33 & 2,83 & 4,33 \\
\hline 5 & $\begin{array}{l}\text { Cara Guru mendengarkan dan memberikan } \\
\text { perhatian terhadap semua jawaban peserta didik } \\
\text { baik yang benar maupun yang dianggap salah untuk } \\
\text { mengukur tingkat pemahaman peserta didik }\end{array}$ & 2,00 & 3,33 & 4,50 \\
\hline 6 & $\begin{array}{l}\text { Cara Guru memberikan perhatian terhadap } \\
\text { pertanyaan peserta didik dan meresponnya secara } \\
\text { lengkap dan relevan untuk menghilangkan } \\
\text { kebingungan pada peserta didik. }\end{array}$ & 2,00 & 3,66 & 4,50 \\
\hline \multicolumn{2}{|r|}{ Prosentase skor rata-rata } & 1,69 & 3,30 & 4,41 \\
\hline
\end{tabular}

Tabel 5

Perincian peningkatan kemampuan guru dalam berkomunikasi dengan peserta didik

\begin{tabular}{|c|l|c|c|c|}
\hline No & \multicolumn{1}{|c|}{ Indikator } & Prasiklus & Siklus I & Siklus II \\
\hline 1 & $\begin{array}{l}\text { Cara Guru menggunakan pertanyaan untuk } \\
\text { mengetahui pemahaman dan menjaga } \\
\text { partisipasi peserta didik, termasuk memberikan } \\
\text { pertanyaan terbuka yang menuntut peserta didik } \\
\text { untuk menjawab dengan ide dan pengetahuan } \\
\text { mereka. }\end{array}$ & 30,00 & 66, & 86,60 \\
\hline 2 & $\begin{array}{l}\text { Cara guru memberikan perhatian dan } \\
\text { mendengarkan semua pertanyaan dan tanggapan } \\
\text { peserta didik, tanpa menginterupsi, kecuali jika } \\
\text { diperlukan untuk membantu atau } \\
\text { mengklarifikasi pertanyaan/tanggapan tersebut }\end{array}$ & 36,66 & 66, & \\
\hline 3 & Cara Guru menanggapi pertanyaan peserta didik & 30,00 & 60,00 \\
\hline
\end{tabular}




\begin{tabular}{|c|l|r|r|r|}
\hline & $\begin{array}{l}\text { secara tepat, benar, dan mutakhir, sesuai tujuan } \\
\text { pembelajaran dan is kurikulum, tanpa } \\
\text { mempermalukannya }\end{array}$ & & 66 & \\
\hline 4 & $\begin{array}{l}\text { Cara Guru menyajikan kegiatan pembelajaran } \\
\text { yang dapat menumbuhkan kerja sama yang baik } \\
\text { antar pserta didik. }\end{array}$ & 26,66 & 56, \\
\hline 5 & $\begin{array}{l}\text { Cara Guru mendengarkan dan memberikan } \\
\text { perhatian terhadap semua jawaban peserta didik } \\
\text { baik yang benar maupun yang dianggap salah } \\
\text { untuk mengukur tingkat pemahaman peserta } \\
\text { didik }\end{array}$ & 66,00 & 66, & 90,00 \\
\hline 6 & $\begin{array}{l}\text { Cara Guru memberikan perhatian terhadap } \\
\text { pertanyaan peserta didik dan meresponnya } \\
\text { secara lengkap dan relevan untuk } \\
\text { menghilangkan kebingungan pada peserta didik. }\end{array}$ & 40,00 & 73, & 90,00 \\
\hline Prosentase skor rata-rata & 33,86 & 66,06 & 88,30 \\
\hline
\end{tabular}

Dari tabel tersebut di atas dapat diketahui bahwa aspek yang perlu mendapat perhatian adalah cara Guru mendengarkan dan memberikan perhatian terhadap semua jawaban peserta didik baik yang benar maupun yang dianggap salah untuk mengukur tingkat pemahaman peserta didik dimana pada aspek tersebut baru mencapai $88,30 \%$.

\section{Kesimpulan}

Berdasarkan hasil penelitian dan pembahasan dapat disimpulkan bahwa melalui Supervisi klinis dapat meningkatkan kemampuan guru dalam berkomunikasi dengan peserta didik di SD Negeri 5 Surabaya. Pada semester I tahun ajaran 2016/2017. Peningkatan itu terdapat pada kemampuan guru dalam berkomunikasi dengan peserta didik dari siklus ke siklus mengalami peningkatan, yaitu dari prasiklus $33,86 \%$, siklus I sebesar 66,06\%, dan siklus II sebesar 88,30\%. Peningkatan selama tindakan adalah $54,44 \%$. Peningkatan terjadi pada semua aspek. Terjadinya peningkatan kemampuan guru tersebut disebabkan adanya kegiatan pembinaan yang berdasarkan penilaian yang obyektif yang disampaikan secara transparan kepada guru, selain itu pelaksanaan supervisi dengan jumlah guru yang kecil cenderung memudahkan komunikasi antara peneliti, kepala sekolah dan Guru. Adanya supervisi tersebut meningkatkan kesadaran guru akan pentingnya kemampuan dalam berkomunikasi dengan peserta didik, dan menumbuhkan kesadaran guru bahwa kemampuan tersebut merupakan salah satu aspek penilaian kinerja guru

\section{Daftar Pustaka}

Basamala, Bismar, 2012, Kemampuan Guru Dalam Berkomunikasi Sumbangsihnya Dalam Pemahaman Materi.http://teropongtemukandisinibasalama bismar.blogspot.com DeVito, Joseph A. 2007. Komunikasi

Antarmanusia. Jakarta: Proffesional Books. Djamarah, Syaiful Bahri. 2005. Guru dan Anak Didik Dalam Interaksi Edukatif Suatu

Pendekatan teoritis Psikologis. Jakarta: PT. Rineka Cipta.

Mulyasa. 2006. Kurikulum Tingkat Satuan Pendidikan. Bandung: PT. Remaja Rosdakarya. Sagala, Syaiful. 2009. Kemampuan Profesional Guru dan Tenaga Kependidikan. Bandung:

Alfabeta.

Sarimaya, Farida. 2008. Sertifikasi Guru, Apa, Mengapa dan Bagaimana. Bandung: CV. Yrama Widya.

Saudagar, Fachruddin, Ali Idrus. 2006.

Pengembangan Profesionalitas Guru. Jakarta:

Gaung Persada Press.

Sukmadinata, Nana Syaodih, 2007, Landasan Psikologi Proses Pendidikan, Penerbit PT.

Remaja Rosdakarya, Bandung. 